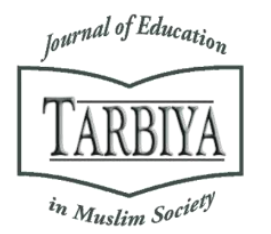

Available online at TARBIYA: Journal of Education in Muslim Society Website:

http://journal.uinjkt.ac.id/index.php/tarbiya

TARBIYA: Journal of Education in Muslim Society, 5(2), 2018, 166-177

\title{
THE ABILITY OF STUDENTS' SCIENTIFIC ARGUMENTATION OF ACID-BASE AND BUFFER SOLUTION THROUGH SCIENCE WRITING HEURISTIC (SWH)
}

\author{
R. Arizal Firmansyah, Linda Hesti Kumala \\ UIN Walisongo semarang, Indonesia \\ E-mail: r.arizalfirmansyah@walisongo.ac.id
}

Received: $15^{\text {th }}$ August 2018; Revised: $25^{\text {th }}$ November 2018; Accepted: $28^{\text {th }}$ December 2018

\section{Abstract}

Many students have found the difficulties to give proper evidence scientifically. Therefore, it is necessary to provide the learning approach model which guides students to argue scientifically on the laboratory work writing namely science writing heuristic $(\mathrm{SWH})$. In this research, we tried to describe the quality of students scientific argumentation on acid-base and buffer solution laboratory work writing through mixed methods embedded concurrent. The research data was obtained through assessment rubric of ability scientific argumentation SWH formatted and field notes. The overall of ability scientific argumentation was moderate $(63.60 \%)$. From this research, we found that laboratory work writing with laboratory report SWH formatted can improve students' ability on their scientific argumentation.

Keywords: evidence; laboratory work; inquiry

\section{Abstrak}

Banyak pelajar telah menemukan kesulitan untuk memberikan bukti yang tepat secara ilmiah. Oleh karena itu, perlu untuk menyediakan model pendekatan pembelajaran yang memandu pelajar untuk berdebat secara ilmiah tentang penulisan kerja laboratorium yaitu heuristik penulisan sains (SWH). Dalam penelitian ini, kami mencoba mendeskripsikan kualitas argumentasi ilmiah pelajar pada penulisan kerja laboratorium larutan asam-basa dan buffer melalui metode campuran yang disatukan secara bersamaan. Data penelitian diperoleh melalui rubrik penilaian kemampuan argumentasi ilmiah $S W H$ yang diformat dan catatan lapangan. Keseluruhan argumentasi ilmiah kemampuan adalah sedang (63,60\%). Dari penelitian ini, kami menemukan bahwa penulisan kerja laboratorium dengan laporan laboratorium yang diformat $S W H$ dapat meningkatkan kemampuan pelajar dalam argumentasi ilmiah mereka.

Kata kunci: bukti; pekerjaan laboratorium; penyelidikan

How to Cite : Firmansyah, R. A., Kumala, L. H. (2018). The Ability of Students'scientific Argumentation of AcidBase and Buffer Solution Through Science Writing Heuristic (SWH). TARBIYA: Journal of Education in Muslim Society, 5(2), 166-177. doi:10.15408/tjems.v5i2.10412.

Permalink/DOI: http://dx.doi.org/10.15408/tjems.v5i2.10412

TARBIYA: Journal of Education in Muslim Society, P-ISSN: 2356-1416, e-ISSN: 2442-9848 


\section{Introduction}

The laboratory activities in education field only were claimed to confirming the information from the textbook or teachers' explanation (Wickman, 2004). Also, the purpose of learning process in laboratory is limited to improve the students' cognitive domain only, while other aspects such as creative thinking and problem solving are not noticed (Abrahams and Millar, 2007). However, as time goes by, learning in the laboratory has paid attention to these aspects and the learning design has been oriented to the inquiry. Including the experiment manual used is highly synchronized from the "cookbook" to the instruction manuals that train students to argue based on experimental facts (Hofstein and Lunetta, 2003; Hofstein, 2004; Reid and Shah, 2007; Wheeler et al., 2015; Akkuzu and Uyulgan, 2017; Crujeiras-Pèrez and JimènezAleixandre, 2017; Wheeler et al., 2019). Moody and Foster (1997) offered laboratory approach that asked students to read of material and during this activity instructor discuss about the theory and practical advice also can be introduced. In contrast to Tsaparlis and Gorezi (2007) who have successfully added the project to the traditional practice so that initially monotony with the addition of the project, the experiment becomes more attractive. Modification of other traditional experiment is a practical approach to laboratory assistants (Hong-BinYu, 2015). Domin (1999), Fay et al. (2007) categorized the experiment work into four types, namely expository, inquiry, discovery and problem-based. These types of experiment work depend on the role of teacher. However, many schools do not conduct practical work since tools and chemicals are incomplete. One of them is MAN 1 Pati in Central Java. The ongoing chemical learning is still teachercentred. Students got the chemistry knowledge was only from their teacher explanations. It will decrease students' curiosity towards chemistry and students difficult to understand the concepts and lacking practical skills (Shulman and Tamir 1973). Therefore, it is necessary to carry out the practical work that allows students to do inquiry skills so that process skills and chemical knowledge are improved (Hodson, 1990; Chebii et al., 2012). One is Process Oriented Guided Inquiry Learning (POGIL) (Soltis et al., 2015; Rivers, 2002; Weaver et al., 2008). At the time of the lab for students' inquiry skills to be more comprehensive, students need writing assignment because it will help students understand the concept of chemistry more deeply (Kovac and Sherwood, 1999). Writing an experiment report can improve students' conceptual understanding better. Besides that it trains students imitate a chemist since students to organize experiment data into meaningful information or problem solving (Thomas et al., 2015). One of these experiment report formats uses a Heuristic strategy known as Science writing Heuristic (SWH). Practical report writing with SWH format refers to learning cycle theory (Lawson et al., 1989; Keys et al., 1999).

The SWH consists of titles in the form of questions, probation procedures, temporary claims, and evidence. This SWH format report is similar to the mini-journal developed by Zhao and Wardeska (2011). At this stage, the filing of evidence that the student is required to explain why the proof is appropriate to support a temporary answer earlier. The last stage, a reflection that asks students to compare the discussion (claim and evidence) with the experiments that have been done (Schroeder and Greenbowe, 2007; Burke and Greenbowe, 2006; Rudd II, Greenbowe and Hand, 2007).

Based on the stages in the SWH report, it is learning style of inquiry or problem-based experiment (Domin, 1999; Domin, 2009; Moskovitz and Kellog, 2011). The benefits of the SWH report format are encouraged students to understand the concept of chemistry more 
deeply and high-order thinking skill (Schroeder and Greenbowe, 2007; Burke and Greenbowe, 2006; Rudd II, Greenbowe and Hand, 2007, Rudd II, et al., 2001; Poock et al., 2007; Bruck and Towns, 2009; Putti, 2011). This article provides a description of how the quality of students' arguments MAN 1 Pati who previously never practised and writing arguments through SWH formatted laboratory reports.

\section{Methods}

This research used Mix Methods with Embedded Concurrent approach. The sample is class XI IPA-1 MAN 1 PATI (32 students). It was collected by purposive sampling technique.
This technique is chosen because the teacher better understands students' cognitive, affective and psychomotoric abilities.

The theoretical learning was on acid-base material and buffer solution with POGIL approach. When the students would like to do the experiment work, the explanation was given descriptively to them about how the quality of scientific arguments written by students. The quality of students' scientific argumentation was evaluated by the rubric of scientific argumentation capability assessments referring to Akkus et al. (2007); Schroeder and Greenbowe (2007); (Walker et al.2011). The score of Scientific Argument Ability's students are converted to qualitative data (Widyoko, 2009).

Table 1. Assesment Rubric of Scientific Argument Ability SWH oriented (Walker et al.2011)

\begin{tabular}{|c|c|c|c|}
\hline No. & Aspects & Scale & Description \\
\hline \multirow[t]{3}{*}{1.} & $\begin{array}{l}\text { Able to provide evidence } \\
\text { of investigation results }\end{array}$ & 3 & $\begin{array}{l}\text { Includes }>75 \% \text { of investigation data in data formats (diagrams, graphs, or } \\
\text { labels). }\end{array}$ \\
\hline & & 2 & $\begin{array}{l}\text { Includes } 50 \%-75 \% \text { of investigation data in data format (diagrams, graphs, or } \\
\text { labels). }\end{array}$ \\
\hline & & 1 & $\begin{array}{l}\text { Include only }<50 \% \text { of data of investigation results with data format (diagrams, } \\
\text { graphs, or labels). }\end{array}$ \\
\hline \multirow[t]{3}{*}{2.} & $\begin{array}{l}\text { Able to make the claim to } \\
\text { answer the inquiry } \\
\text { question }\end{array}$ & 3 & $\begin{array}{l}\text { Able to make statements (claims) based on theories, data/evidence, and/or other } \\
\text { support as many as }>5 \text { claims correctly. }\end{array}$ \\
\hline & & 2 & $\begin{array}{l}\text { Able to make statements (claims) based on theory, data/evidence, and/or other } \\
\text { support as many as } 3-5 \text { claims correctly. }\end{array}$ \\
\hline & & 1 & $\begin{array}{l}\text { Able to make statements (claims) based on theory, data/evidence, and/or other } \\
\text { support of as many as }<3 \text { claims correctly. }\end{array}$ \\
\hline \multirow[t]{3}{*}{3.} & $\begin{array}{l}\text { Able to use evidence of } \\
\text { investigation results to } \\
\text { claims }\end{array}$ & 3 & $\begin{array}{l}\text { Capable of explaining data/evidence from } 3-4 \text { experiments to underpin } \\
\text { statements (claims). }\end{array}$ \\
\hline & & 2 & $\begin{array}{l}\text { Able to explain data/evidence from second experiments to underlying statement } \\
\text { (claim). }\end{array}$ \\
\hline & & 1 & $\begin{array}{l}\text { Able to explain data/evidence from } 1 \text { experiment to underlying statement } \\
\text { (claim). }\end{array}$ \\
\hline \multirow[t]{3}{*}{4.} & $\begin{array}{l}\text { Be able to write the } \\
\text { reasons }\end{array}$ & 3 & $\begin{array}{l}\text { Be able to write the reasons (justification and support) using internal and } \\
\text { external sources of data/evidence to support claims on acid-base statements and } \\
\text { buffer solutions (both). }\end{array}$ \\
\hline & & 2 & $\begin{array}{l}\text { Be able to write the reasons (justification and support) using internal or external } \\
\text { sources of data/evidence to support the claim (claims) on the acid-base } \\
\text { statements and/or buffer solutions (any). }\end{array}$ \\
\hline & & 1 & $\begin{array}{l}\text { Not writing reasons (justification and support) using internal and external } \\
\text { sources (not both) to support the claim (claim). }\end{array}$ \\
\hline \multirow[t]{3}{*}{5.} & $\begin{array}{l}\text { Able to } \\
\text { arguments } \\
\text { hypothesis }\end{array}$ & 3 & $\begin{array}{l}\text { Able to associate arguments with hypothesis on acid-base statements and buffer } \\
\text { solutions. }\end{array}$ \\
\hline & & 2 & $\begin{array}{l}\text { Able to associate arguments with hypothesis on acid-base statements or on } \\
\text { buffer solutions. }\end{array}$ \\
\hline & & 1 & Do not associate arguments with hypothesis. \\
\hline
\end{tabular}


Table 2. conversion scores of scientific argument ability each aspect to category (Widyoko, 2009)

\begin{tabular}{lll}
\hline Score interval & Percentage & Category \\
\hline$X>\bar{X} i+1,80 \times S B i$ & $\mathrm{X}>86,33 \%$ & Very good \\
$X>2+1,80 \times 0,33$ & & \\
$X>2,59$ & & \\
$\bar{X} i+0,60 \times S B i<X \leq \bar{X} i+1,80 \times S B i$ & $73,00 \%<\mathrm{X} \leq 86,33 \%$ & Good \\
$2+0,60 \times 0,33<X \leq 2+1,80 \times 0,33$ & & \\
$2,19<X \leq 2,59$ & & \\
$\bar{X} i-0,60 \times S B i<X \leq \bar{X} i+0,60 \times S B i$ & $60,33 \%<\mathrm{X} \leq 73,00 \%$ & Enough \\
$2-0,60 \times 0,33<X \leq 2+0,60 \times 0,33$ & & \\
$1,81<X \leq 2,19$ & & \\
$\bar{X} i-1,80 \times S B i<X \leq \bar{X} i-0,60 \times S B i$ & $47,00 \%<\mathrm{X} \leq 60,33 \%$ & Less \\
$2-1,80 \times 0,33<X \leq 2-0,60 \times 0,33$ & & \\
$1,41<X \leq 1,81$ & & \\
$X \leq \bar{X} i-1,80 \times S B i$ & $\mathrm{X} \leq 47,00 \%$ & \\
$X \leq 2-1,80 \times 0,33$ & & \\
$X \leq 1,41$ & & \\
\hline
\end{tabular}

\section{Result and Discussion}

Based on the assessment of three observers through the SWH-oriented scientific argument ability rubric (Table 2), results is shown in Table 3 .

Table 3. Average Scores of Student Scientific Overall Scientific Ability on Writing SWH-Oriented Practicum Reports

\begin{tabular}{|c|c|c|c|c|}
\hline No. & $\begin{array}{l}\text { Aspects of Scientific } \\
\text { Argument Ability }\end{array}$ & Average & Percentage & Category \\
\hline 1. & $\begin{array}{lcc}\text { Aspects } & \text { of Ability } & \text { to } \\
\text { Provide } & \text { Evidence } & \text { of } \\
\text { Inquiry } & & \\
\end{array}$ & 2,13 & $71,00 \%$ & Enough \\
\hline 2. & $\begin{array}{l}\text { Aspects of Ability to } \\
\text { Make a Statement or } \\
\text { Claim for Answering the } \\
\text { Inquiry Question }\end{array}$ & 1,56 & $52,00 \%$ & Less \\
\hline 3. & $\begin{array}{l}\text { Aspects of Ability to Use } \\
\text { Data or Evidence of } \\
\text { Inquiry to Explain claims }\end{array}$ & 1,98 & $66,00 \%$ & Enough \\
\hline 4. & $\begin{array}{l}\text { Aspects of Ability to } \\
\text { Write the Reason } \\
\text { (justification and support) } \\
\text { of the Data / Evidence to } \\
\text { Support the claim }\end{array}$ & 2,02 & $67,33 \%$ & Enough \\
\hline 5. & $\begin{array}{l}\text { Aspects of Ability to } \\
\text { Relate Arguments to } \\
\text { Hypothesis }\end{array}$ & 1,83 & $61,00 \%$ & Enough \\
\hline $\begin{array}{l}\text { Total } \\
\text { Argun }\end{array}$ & $\begin{array}{c}\text { Aspect of Scientific } \\
\text { ent Ability }\end{array}$ & 9,54 & $63,60 \%$ & Enough \\
\hline
\end{tabular}

Based on table 3, it can be seen that the average overall score of the results of the assessment of scientific argumentation ability is 63.60\% with sufficient category (enough). The results obtained are not satisfactory because the first new students to carry out experiment activities and write a report so that data written experiments are mostly still less precise, consequently the aspects of writing the report oriented SWH less satisfactory as well. These results are not as obtained in previous research reporting (Cooper and Oliver-Hoyo, 2016). Although the results obtained show less significant, at least with the assignment to making SWH-oriented practice reports provide a new learning experience of students of MAN 1 Pati who had never practised before. Learning experiences such as students is required to make a question. Starting from this question the stages in the SWH will run (Cronje et al., 2013; Burke and Greenbowe, 2006; Rudd II et al., 2007; Cooper and Oliver-Hoyo, 2016; Shamuganathan and Karpudewan, 2017; Stephenson and Sadler-McKnight, 2016). Even this question, if examined from the aspect of research, will provide the identity of how far the research is up to date (Farrugia et al., 2010). Also to being demanded to ask questions, the SWHoriented report requires students to make hypothesis claims, submit evidence (evidence) and the reason why the evidence that has been obtained from the experimental results can support or reject the hypothesis. The stages of the SWH report actually invite students to think, write and work as scientists think, write and work (Thomas et al., 2015; Krieter et al., 2015; Zeir, et al., 2016; Graulich et al. , 2009; Graulich,2015; McClaryand Talanquer,2011). 
In table 3 , the ability to make the answer is the smallest compared to other aspects $(52.00 \%)$. This is because in this aspect the students have difficulties in determining the $\mathrm{pH}$ estimate of the solution so that they can not make a temporary answer and there is also the answer while the student is still less precise (table 4), that is "From the experimental results the solution types $\mathrm{A}, \mathrm{B}, \mathrm{C}$ and $\mathrm{D}$ have the difference slight or relatively fixed $\mathrm{pH}$ changes ". From the report on the buffer solution, it can be seen that in writing the claim is still less precise, because it has not been able to answer the experiment question correctly. The question posed is "how is the effect of adding acid, base and dilution to buffer solution?" So the supposedly temporary answer is "adding a little strong acid, strong base and dilution to buffer solution has no significant effect".

\section{Table 4. Summary of Field Notes}

\begin{tabular}{|c|c|c|}
\hline No. & Aspects & Field Notes \\
\hline \multirow[t]{2}{*}{1} & $\begin{array}{l}\text { Provide data of } \\
\text { investigation } \\
\text { results }\end{array}$ & $\begin{array}{l}\text { In experiment } 2 \text {, the average student did not } \\
\text { write the estimate results of the } \mathrm{pH} \text { of the } \\
\text { solution and did not specify the nature of } \\
\text { the solution in the observed data. }\end{array}$ \\
\hline & & $\begin{array}{l}\text { There was one student who only included } \\
\text { data in experiment } 1 \text {. } \\
\text { In the buffer solution report, the average } \\
\text { student is not appropriate in classifying the } \\
\text { properties of the solution, because the result } \\
\text { of pH measurement data obtained by the } \\
\text { students is also much less precise. }\end{array}$ \\
\hline \multirow[t]{4}{*}{2} & $\begin{array}{l}\text { Make claim to } \\
\text { answer the }\end{array}$ & $\begin{array}{l}\text { In the experimental acid-base report } 2 \text {, the } \\
\text { average student did not make claim. }\end{array}$ \\
\hline & & $\begin{array}{l}\text { In experiments } 2 \text { and } 3 \text {, there were } 14 \\
\text { students who did not make claim. }\end{array}$ \\
\hline & & $\begin{array}{l}\text { In the buffer solution report, the average } \\
\text { student is still less precise in making a claim. }\end{array}$ \\
\hline & & $\begin{array}{l}\text { There are } 7 \text { students who make a claim } \\
\text { correctly. }\end{array}$ \\
\hline \multirow[t]{2}{*}{3} & $\begin{array}{l}\text { Use the } \\
\text { investigation data } \\
\text { to support the } \\
\text { claim }\end{array}$ & $\begin{array}{l}\text { the majority of students have not been able } \\
\text { to explain all data from table form to } \\
\text { written form to underlying claims. } \\
\text { All students are not using data in } \\
\text { experiment } 2 \text {. }\end{array}$ \\
\hline & & $\begin{array}{l}\text { In the buffer solution report, the average } \\
\text { student can already use the data to base the } \\
\text { claim. } \\
\text { There are four students who can not explain } \\
\text { their experiment data to support the claim. }\end{array}$ \\
\hline 4 & $\begin{array}{l}\text { Write down the } \\
\text { reasons to } \\
\text { support the claim }\end{array}$ & $\begin{array}{l}\text { Students have compared their claims, but on } \\
\text { average they do not make a complete claim. } \\
\text { There is one student who only compares } \\
\text { data with internal sources only. }\end{array}$ \\
\hline
\end{tabular}

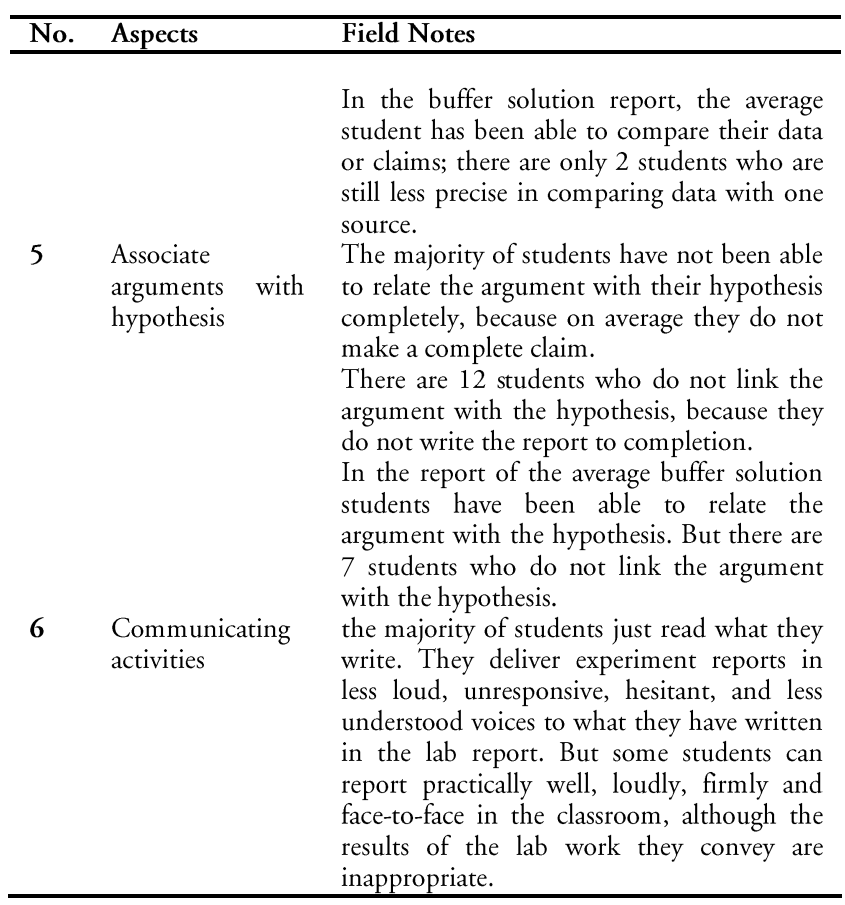

The next aspect is the ability to use data or evidence of investigation results to explain claims. Ability in this aspect is only $66.00 \%$ (enough). This capability is indicated by the appearance of two experiments described by students from 4 experiments on report writing of acid-base experiment and buffer solutions. Here's an example of student writing on this aspect,

"The proof of my claim is that on the basis of experiment 1 the acid solution are a solution which can break the litmus paper, the basic solution is a solution that can brighten the litmus paper. And based on experiment 3 acid solution is solution having $\mathrm{pH}<7$, alkaline solution is solution having $\mathrm{pH}>7$ ".

It appears on students' writing that the data or evidence written to base their temporary answers is unclear. This is indeed an observation, not yet able to explain or translate in detail all the data obtained from the table form of written form to underlie their claims (table 3). They should write at least the following,

"Experiment 1: The proof of my claim is that when electrolyte $\mathrm{A}$ and $\mathrm{B}$ solutions are tested with red litmus paper it still produces 
a red color and when tested with a blue litmus paper produces a red color. While when the electrolyte solution C and D in the test of red litmus paper produces the blue color and when tested for a blue litmus paper still produce blue color. It can be concluded that solutions $\mathrm{A}$ and $\mathrm{B}$ are acidic solutions because they can dispense litmus paper and solutions $\mathrm{C}$ and $\mathrm{D}$ are basic solutions because they can brighten litmus paper ".

Experiment 2: The proof of my claim is that when the electrolyte solution $\mathrm{A}$ and $\mathrm{B}$ is added the orange methyl indicator produces a red color, added red methyl yields a red color, added a blue bromthymol produces a yellow color, added colorless phenolphthalein and $\mathrm{pH}$ of electrolyte $\mathrm{A}$ and $\mathrm{B}$ solution $<8,2$. Whereas when the electrolyte solution $\mathrm{C}$ and $\mathrm{D}$ was added the methyl orange indicator yielded a yellow color, added red methyl yielding yellow color, solution $\mathrm{C}$ added a blue bromtonol yield dark green color, solution $\mathrm{D}$ added bromthymol blue yielding yellow color, solution $\mathrm{C}$ added phenolphthalein yield red, $\mathrm{D}$ is added colorless phenolphthalein and $\mathrm{pH}$ of electrolyte solution $\mathrm{C}>10, \mathrm{pH}$ of solution D 5,8 - 8,2 ". It can be concluded that solutions $\mathrm{A}$ and $\mathrm{B}$ are acidic solutions because they show an estimate of $\mathrm{pH}<8.2$ and solutions $\mathrm{C}$ and $\mathrm{D}$ are basic solutions because they show an estimate of $\mathrm{pH}>10$ and $5.8-8.2$.

"Experiment 3: The proof of my claim was that when the electrolyte A solution to the test of the universal indicator showed $\mathrm{pH} 2$, the electrolyte solution $\mathrm{B}$ showed $\mathrm{pH} 4$, the electrolyte solution $\mathrm{C}$ showed $\mathrm{pH} 12$, and the electrolyte solution $\mathrm{D}$ showed $\mathrm{pH}$ 8. So it can be concluded that the solution $\mathrm{A}$ and $\mathrm{B}$ is an acidic solution having a $\mathrm{pH}<7$ and the solution of $\mathrm{C}$ and $\mathrm{D}$ is an alkaline solution having a $\mathrm{pH}>7$ ".

While the students' buffer reports do not use experimental data to base their claims, as there are some students who only write one report of the lab alone (only acids or buffer alone).

The next aspect is the ability to write down the reasons for supporting temporary answers. In this aspect the students are asked to write down the reason for the data to support their claim. The purpose of writing the reasons for using internal and external sources is to strengthen student's claims. They are trained to argue not only based on the data they get, but also based on data obtained by others, so that the data obtained can be compared to finding out whether the claims made have the same conclusions or not. The internal sources in question are comparing and discussing the data obtained with a classmate, while the external source is comparing data obtained with books, articles or the internet (Walker and Sampson, 2013). Here's an example of this aspect,

"Internal Source: after I compare or discuss my data with my classmates it turns out that the data we get has the same conclusion that the acid solution can break the litmus paper and the alkaline solution can brighten the litmus paper"."External sources: based on external sources (books, articles, internet) that I read also mentions that acid solutions can redden the blue litmus".

It appears in the above examples that students have compared their temporary answers to classmates' claims and other sources, but most of them have not been able to compare and explain in detail all of their claims on the experiment, as most of them do not make a complete claim. They should write at least the following, 
"Internal Source: after I compare or discuss my data with classmates it turns out that the data we get has the same conclusion that the acid solution can break the litmus paper and the alkaline solution can brighten the litmus paper. Acid and base solutions are solutions which when added acid-base indicator: methyl orange, red methyl, bromthymol blue, and phenolphthalein will produce predictable colors of their $\mathrm{pH}$ value, ie acid solutions are solutions having a $\mathrm{pH}<7$ and an alkaline solution having $\mathrm{pH}>7$ ".

"External sources: based on external sources (books, articles, internet) I read also mentions that acid solutions can redden the blue litmus paper and alkaline solutions can brighten red litmus paper. Acid and base solutions are solutions which when added acid-base indicator: methyl orange, red methyl, bromthymol blue, and phenolphthalein will produce predictable colors of their $\mathrm{pH}$ value, ie acid solutions are solutions having a $\mathrm{pH}<7$ and an alkaline solution having $\mathrm{pH}>7$ ".

While the report on the buffer solution students did not write reasons to support their claims. Whereas students should write down reasons to support their claims. Here's an example that students do not write down reasons to support their claims, "Internal sources: after I compare and discuss it, my data onto classmates has little difference but have the same conclusion that buffer solution is a solution that has a relatively fixed $\mathrm{pH}$ after a little acid, alkaline and dilution".

"An external source: based on the literature I read also mentions that a buffer solution is a solution that can maintain the $\mathrm{pH}$ from the addition of acids, bases and dilutions, thus having a relatively fixed $\mathrm{pH} "$.

The two aspects above are the ability to use the evidence to explain a temporary answer and the ability to write reasons (justification and support) to the data, giving students the opportunity to articulate evidence or experimental results and temporary answers. Whether the evidence generated in the experiment support or even contradicts a temporary answer (McNeill, 2011; Walker and Sampson, 2013; Knight and McNeill, 2015). Thus these aspects train students to think critically (Walker et al, 2011; Sampson and Walker, 2012; Walker and Sampson, 2013) and reflect how deep the students' concept of understanding is. The last aspect of linking arguments with the hypothesis is to train students to think reflectively (enough category, $61.00 \%)$. Whether the results have been obtained during the experiment changes or support the previous hypothesis and how far the students' knowledge has been gained from the experiment. Here's an example of reflective thinking of students,"My hypothesis is correct that acid is a substance that can break down litmus paper and have a $\mathrm{pH}<7$, whereas a base is a substance that can brighten a litmus paper and have a $\mathrm{pH}>7 "$.

Examples of reflective thinking are less than perfect because they only associate with hypothesis. Should at least students write it as follows,

"My hypothesis is correct that the acid solution are a solution that can break with the litmus paper and when added acid-base indicator: methyl orange, red methyl , bromthymol blue, and phenolphthalein will result in red, red, yellow and colorless, $\mathrm{pH}$ $<7$. While the alkaline solution is a solution which can brighten the litmus paper and when added acid-base indicator: methyl orange, red methyl, bromthymol blue, and phenolphthalein will result in yellow, yellow, dark green or yellow, red or not colored, and have a $\mathrm{pH}>7$ ". 
After students write SWH-oriented reports, they are asked to present in front of the results class of their group. In this section the quality of the argument will be assessed. Based on field notes it was found that during presentation activities, most students only read what they write. They deliver experiment reports less loud, unresponsive, hesitant, and less understood voice to what they have written in the lab report. But some students can report practically well, loudly, firmly and face-to-face in the classroom, even though the results of the lab work are poor (table3). The results of this study as a whole did not show satisfactory results, only $63.60 \%$ (enough category). This is because students are still not familiar with the writing of SWHoriented reports. Even they are also in the daily learning of chemistry, never experiment. Nevertheless, SWH-oriented reports writing still have the potential to be better implemented and sufficient time will result in satisfactory learning outcomes, as Kingir et al. (2012). Assignment to practical report writing can help students understand the concept better indicated by the absence of different post-test results from low and high ability students.

To further increase students' interest in chemistry learning and to help students understand deeper concepts, the issues of daily life such as environmental themes can be combined with practical and laboratory reports (Kingir, et al., 2012; Juntunen and Aksela , 2014; Mandler, et al., 2012; Shamuganathan and Karpudewan, 2017). Other matters based on the results of this study (from field notes and assessment of SWH experiment report), it is suggested in the writing of SWH practice reports using the version of McNeill et al. (2006) because it is more appropriate for students that have not adapted to practical learning environments and the steps in the McNeill et al. (2006) version makes it easier to argue scientifically, although Cooper and Oliver-Hoyo
(2016) study results state that the quality of Sandoval's argumentation (2003) is better than the version of McNeill et al. (2006). The results of this study also suggest further research on how to understand students' concepts if writing SWH-oriented experiment reports on McNeill et al. (2006) or Walker et al. (2011) than Sandoval (2003). The students' understanding of the concept can be done in designing the problem as reported by Rudd II et al. (2001). Also, modify the design of the report of McNeill et al. (2006) version or Walker et al. (2011) and Sandoval (2003) versions to suit the characteristics of high school or MA students in Indonesia. Also, it also encourages the design of inquiry learning that is appropriate to the characteristics of students in Indonesia (Abraham, 2011; $\mathrm{Xu}$, and Talanquer, 2013) because the design of learning in the laboratory is also related to the writing of reports that require students to think high level (Cacciatore and Sevian , 2006). And lastly, it is necessary to research how to evaluate Sampson and Clark (2008) based practice reports.

From the results of this study, it can be said that the chemical laboratory have a very important role in learning chemistry. The type of instructional designs will determine the student's learning experience whether laboratory activities of type expository, discovery or inquiry, problem-based learning, or research-based learning. But chemistry learning in the laboratory provides hands-on experience of interacting with chemicals, so that from various types of learning experience in the laboratory it is expected to emerge scientific habits of mind. These habits would emerge better if the learning design in the laboratory was centered on the students (Hofstein and Mamlok-Naaman, 2007; Russell et al., 2014). One of the activities in the laboratory is report-writing. 


\section{Conclusion}

The students' ability to argue scientifically in MAN 1 Pati through writing SWH-oriented reports was in the good enough category $(63.60 \%)$. By this research, we also suggest teacher to more better guide and motivate them through Socratic method especially to connect evidence-reasoning-claims (hypothesis) in writing report (Yuriev et al., 2017). It should be used in every laboratory work. Besides that, the utilizing of the SWH report format that adopts Walker et al. (2011) or McNeill et al. (2006) for students who face difficulties to adapt their learning environment in the laboratory experiment work.

\section{Acknowledgement}

Thank you very much to Headmaster and Chemistry Teacher of MAN 1 Pati who gave permission to conduct our research and supported the collection of research data. Also, the authors thank to Umi Khumaidah and Umi Sa'idatul for the collaboration data collection in this study.

\section{References}

Abraham, M. R. (2011). What Can be Learned from Laboratory Activities? Revisiting 32 Years of Research. Journal of Chemical Education. 88, 1020-1025.

Abrahams, I. and Millar, R. 2007. Does Practical Work Really Work? A study of the effectiveness of practical work as a teaching and learning method in school science. International Journal of Science Education. 30, 1945-1969.

Akkuzu, N. and Uyulgan, M. A. 2017. Step by step learning using the I diagram in the systematic qualitative analyses of cations within a guided inquiry learning approach. Chemistry Education Research and Practice. 18, 641-658.
Bruck, L. B., and Towns, M. H. (2009). Preparing Students To Benefit from Inquiry-Based Activities in the Chemistry Laboratory: Guidelines and Suggestions. Journal of Chemical Education. 86, 820-822.

Burke, K. A., Greenbowe, T. J. and Hand, B. M. (2006). Implementing the Science Writing Heuristic in the Chemistry Laboratory. Journal of Chemical Education. 83, 10321038 .

Cacciatore, K. L., and Sevian. H. (2006). Teaching Lab Report Writing through Inquiry: A Green Chemistry Stoichiometry Experiment for General Chemistry. Journal of Chemical Education. 83, 1039-1041.

Chebii, R., Wachanga, S., Kiboss, J. (2012). Effects of science process skills mastering learning Approach on students' Acquisition of selected chemistry practical skills in school. Creative Education, 3, 1291-1296.

Chemistry Education Research and Practice. 13, 428-436.

Cooper, A. K and Oliver-Hoyo, M. T. (2016). Argument Construction In Understanding Noncovalent Interactions: A Comparison Of Two Argumentation Frameworks. Chemistry Education Research and Practice. 17, 10061018 .

Cronje, R., Murray, K., Rohlinger, S., and Wellnitz, T. (2013). Using the Science Writing Heuristic to

Crujeiras-Pèrez, B. and Jimènez-Aleixandre, M. P. 2017. High school students' engagement in planning investigations: findings from a longitudinal study in Spain. Chemistry Education Research and Practice. 18, 99-112.

Domin, D. S. (1999). A Review of Laboratory Styles. Journal of Chemical education. 75. 543-547.

Domin, D. S. (2009). Considering Laboratory Instruction through Kuhn's View of the Nature of Science. Journal of Chemical education. 86. 274-277. 
Fay, M. E., Grove, N. P., Towns, M. H., and Bretz, S. L. 2007. A rubric to characterize inquiry in the undergraduate chemistry laboratory. Chemistry Education Research and Practice. 8, 212-219.

Graulich, N. (2015). Intuitive Judgments Govern Students' Answering Patterns in MultipleChoice Exercises in Organic Chemistry. Journal of Chemical Education. 92, 205-211.

Graulich, N., Hopf, H., and Schreiner, P. R. (2009). Heuristic Thinking makes a Chemist Smart. Chemical Society Reviews. 39, 1503-1512.

Hodson, D. (1990). A Critical Look at Practical Work in School Science, School Science Review, 71, 33-40.

Hofstein, A. (2004). The Laboratory In Chemistry Education: Thirty Years Of Experience With Developments, Implementation, And Research. Chemistry Education: Research and Practice. 5, 247-264.

Hofstein, A. (2004). The Laboratory in Chemistry Education: Thirty Years of Experience With Developments. Implementation, and Research. Chemistry Education Research and Practice. 5, 247-264.

Hofstein, A., and Lunetta, V. N., 2003, The laboratory in science education: Foundations for the twenty-first century. Science Education. 88, 28-54.

Hofstein, A., and Lunetta, V. N., 2004, The laboratory in science education: Foundations for the twenty-first century, Science Education, 88, 28-54.

Hofstein, A., and Mamlok-Naaman. (2007). The laboratory in science education: the state of the art. Chemistry Education Research and Practice. 8, 105-107.

Hong-Bin Yu. (2015). Promoting Chemistry Learning through Undergraduate Work Experience in the Chemistry Lab: A Practical Approach. Journal of Chemical Education. 92, 433-438.
Improve Undergraduate Writing in Biology. International Journal of Science Education. 35, 2718-2731.

Juntunen, M. K., and Aksela, M. K. (2014). Improving students' argumentation skills through a product life-cycle analysis project in chemistry education. Chemistry Education Research and Practice. 15, 639-649.

Keys C. W., Hand B. M., Prain V. and Collins S., (1999), Using the science writing heuristic as a tool for learning from laboratory investigations in secondary science, J. Res. Sci. Teach., 36, 1065-1084.

Kingir, S., Geban, O., and Gunel, M. (2012). How does the science writing heuristic approach affect students'performances of different academic achievement levels? A case for high school chemistry.

Kovac, J. and Sherwood, D. W. (1999). Writing in Chemistry: An Effective Learning Tool. Journal of Chemical Education. 76, 13991403.

Krieter, F. E., Julius, R. W., Tanner, K. D., Bush, S. D., and Scott, G. E. (2016). Thinking Like a Chemist: Development of a Chemistry CardSorting Task To Probe Conceptual Expertise. Journal of Chemical Education. 93, 811-820.

Lawson A., Abraham M. and Renner J., (1989), A theory of Instruction: Using the Learning Cycle to Teach Science Concepts and Thinking Skills, National Association for Research in Science Teaching, Manhattan, KS.

Mandler, D., Mamlok-Naaman, R., Blonder, R., Yayon, M., and Hofstein, A. (2012). Highschool chemistry teaching through environmentally oriented Curricula. Chemistry Education Research and Practice. $13,80-92$.

McClary, L., and Talanquer, V. (2011). Heuristic Reasoning in Chemistry: Making decisions about acid strength. International Journal of Science Education. 33, 1433-1454. 
McNeill, K. L., Lizotte, D. J., Krajcik, J., and Marx, R. W. (2006). Supporting Students' Construction of Scientific Explanations by Fading Scaffolds in Instructional Materials. Journal of the Learning Sciences. 15, 153-191.

Moody, A. E., and Foster, K. A. (1997). The Organic Lab: A Status Quo Report and a Two-Semesters in- One Approach. Journal of Chemical education. 74, 587-591.

Moskovitz, C., and Kellogg, D. (2011). InquiryBased Writing in the Laboratory Course. Science. 332, 919-920.

Poock, J. R., Burke, K. A., Greenbowe, T. J., Hand, B. M. (2007). Using the Science Writing Heuristic in the General Chemistry Laboratory To Improve Students' Academic Performance. Journal of Chemical Education. 84, 1371-822.

Putti, A. (2011). High School Students' Attitudes and Beliefs on Using the Science Writing Heuristic in an Advanced Placement Chemistry Class. Journal of Chemical Education. 88, 516-521.

Reid, N. and Shah, I. 2007. The role of laboratory work in university chemistry. Chemistry Education Research and Practice. 8, 172-185.

Rivers, D. B. (2002). Using A Course-Long Theme For Inquiry-Based Laboratories In A Comparative Physiology Course. Advances in Physiology Education. 26, 317-326.

Rudd II, J. A., Greenbowe, T. J., Hend, B. M., and Legg, M. J. (2001). Using the Science Writing Heuristic to Move toward an Inquiry-Based Laboratory Curriculum: An Example from Physical Equilibrium. Journal of Chemical Education. 78, 1680-1686.

Rudd, II. J. A., Greenvowe, T. J., and Hand, B. M. (2007). Using the Science Writing Heuristic To Improve Students' Understanding of General Equilibrium. Journal of Chemical Education. 84, 2007-2011.
Russell, C. B., Mason, J. D., Bean, T. G., and Murphree, S. S. (2014). A Student-Centered First-Semester Introductory Organic Laboratory Curriculum Facilitated by Microwave-Assisted Synthesis (MAOS). Journal of Chemical Education. 91, 511-517.

Sampson, V., and Clark, D. B. (2008). Assessment of the Ways Students Generate Arguments in Science Education: Current Perspectives and Recommendations for Future Directions. Science Education. 92, 447-472.

Sampson, V., and Walker, J. P. (2012). ArgumentDriven Inquiry as a Way to Help Undergraduate Students Write to Learn by Learning to Write in Chemistry. International Journal of Science Education. 34, 1443-1485.

Sandoval W. A., (2003). Conceptual and epistemic aspects of students' scientific explanations, Journal of the Learning Sciences, 12, 5-51.

Schroeder, J. D., and Greenbowe, T. J. (2007). Implementing POGIL in the lecture and the Science Writing Heuristic in the laboratory student perceptions and performance in undergraduate organic chemistry. Chemistry Education Research and Practice. 9, 149-156.

Shamuganathan, S., and Karpudewan, M. (2017). Science writing heuristics embedded in green chemistry: a tool to nurture environmental literacy among pre-university students. Chemistry Education Research and Practice. 13, 428-436.

Shulman, L. D. and Tamir, P. (1973). Research on teaching in the natural sciences. In R. M. W. Travers (Ed.), Second handbook of research on teaching. Chicago: Rand McNally.

Soltis, R., Verlinden, N., Kruger, N., and Carroll, A., 2015, Process-Oriented Guided Inquiry Learning Strategy Enhances Students' Higher Level Thinking Skills in a Pharmaceutical Sciences Course, American Journal of Pharmaceutical Education, 79, 1-8. 
Thomas, A. C., Boucher, M. A., and Pulliam, C. R. (2015).Qualitative to Quantitative and Spectrum to Report: An Instrument-Focused Research Methods Course for First-Year Students. Journal of Chemical Education. 92, 439-443.

Tsaparlis, G., and Gorezi, M. (2007). Addition of a Project-Based Component to a Conventional Expository Physical Chemistry Laboratory. Journal Of Chemical Education. 84, 668-670.

Walker, J. P., and Sampson, V. (2013). ArgumentDriven Inquiry: Using the Laboratory To Improve Undergraduates' Science Writing Skills through Meaningful Science Writing, Peer-Review, and Revision. Journal of Chemical Education. 90, 1269-1274.

Walker, J. P., and Sampson, V. (2013). Learning to Argue and Arguing to Learn: ArgumentDriven Inquiry as aWay to Help Undergraduate Chemistry Students Learn How to Construct Arguments and Engage in Argumentation During a Laboratory Course. Journal of Research in Science Teaching. 50, 561-596.

Walker, J. P., Sampson, V., and Zimmerman, C. O. (2011). Argument-Driven Inquiry: An Introduction to a New Instructional Model for Use in Undergraduate Chemistry Labs. Journal of Chemical Education. 88, 10481056.

Walker, J. P., Sampson, V., Southerland, S., and Enderle, P. J. (2016). using the laboratory to engage all students in science practices. Chemistry Education Research and Practice. 17, 1098-1113.

Weaver, G. C., Russell, C. B., and Wink, D. (2008). Inquiry-based and Research-based Laboratory Pedagogies in Undergraduate Science. Nature Chemical Biology. 4, 577-580.
Wheeler, L. B., Chiu, J. L., Maeng, J. L., and Bell, R. L. 2019. An exploratory study of teaching assistants' motivation for inquiry-based teaching in an undergraduate laboratory context. Chemistry Education Research and Practice. 20, 53-67.

Wheeler, L. B., Maeng, J. L.., and Whitworth, B. A. 2015. Teaching assistants' perceptions of a training to support an inquiry-based general chemistry laboratory course. . Chemistry Education Research and Practice. 16, 824842.

Wickman, P. O. 2004. The practical epistemologies of the classroom: A study of laboratory work. Science Education. 88, 325-344.

Xu, H., and Talanquer, V. (2013). Effect of the Level of Inquiry of Lab Experiments on General Chemistry Students' Written Reflections. Journal of Chemical Education. 90, 21-28.

Yuriev, E., Naidu, S., Schembri, L. S. and Short, J. L. 2017. Scaffolding the development of problem-solving skills in chemistry: guiding novice students out of dead ends and false starts. Chemistry Education Research and Practice. 18, 486--504.

Zeir, W. G., Zevalkink, A., Gibbs, Z. M., Hautier, G., Kanatzidis, M. G., and Snyder, G. J. (2016). Thinking Like a Chemist: Intuition in Thermoelectric Materials. Angewandte Chemie International Edition. 55, 6826-6841.

Zhao, N., and Wardeska, J. G. (2011). Mini-Journal Inquiry Laboratory: A Case Study in a General Chemistry Kinetics Experiment. Journal of Chemical Education. 88, 452-456. 